\title{
EXPERTISE IN EDUCATION: THEORETICAL ANALYSIS OF BASIC CONCEPTS
}

\author{
Ilona Tryhub \\ ORCID iD 0000-0002-5319-1088 \\ $\mathrm{PhD}$ (Pedagogy), \\ Research Worker, \\ Scientific-Research Laboratory of Educology, \\ Borys Grinchenko Kyiv University, \\ 13-b Tymoshenko Str., 04212 Kyiv, Ukraine \\ i.tryhub@kubg.edu.ua
}

https://doi.org/10.28925/2518-7635.2019.4.5

\section{ABSTRACT}

The article is devoted to theoretical analysis of basic concepts of the problem of expertise in the field of education. It is revealed that ambiguity in the definition of expertise is traced in the scientific literature, as well as the substitution of this concept by similar ones, such as monitoring, diagnostics, inspection, evaluation, audit, control, consulting, etc. It is noted that the above concepts differ in their essence, purpose, tasks, functions, purpose, objects, content, participants, application, technologies, methods, tools and output. The author specifies the essence of theoretical concepts of «expert activity in education» and "expert in the field of education».

Keywords: audit; control; counselling; diagnostics; education expert; evaluation; expert activities in education; expertise; inspection; monitoring.

(c) Tryhub Ilona, 2019

\section{INTRODUCTION}

Education reform in Ukraine, implemented in accordance with European standards, priorities and values, requires the implementation of monitoring and expert support for the functioning of all parts of the education sector. Expertise in the field of education is a way to analyse causal relationships in education, indirectly (through an expert) cognitive process of assessing the quality of education (Ognevyuk, \& Sysoieva, 2015). Expert activity requires high professional competence of specialists, corresponding to their professional training for conducting an expertise.

Scientists investigated the problem of expertise in different directions, in particular studied: philosophical and methodological principles of expertise (O. Anisimov, S. Baronene, A. Tubelskyi), structure of expertise in education (S.Beshelev, F. Ghurvych, V. Cherepanov), scientific and methodological support of expert activity (I. Drannikova, V. Yasvin), expertise of pedagogical objects 
(M.Braun, K. Ross, J.Teilor), opportunities for expertise of educational innovations and educational systems (L. Burkova, T. Novykova, L. Podymova), providing the humanistic nature of the expertise process (A. Asmolov, S. Bratchenko), work with special psychological training practitioners to expertise (L. Loghinova). However, the theoretical foundations of expertise as part of the professional activities of education managers and the ambiguity in defining the term «expertise» are still poorly researched.

The aim of the article is to identify the main basic concepts of the problem of expertise in the field of education and to carry out their scientific analysis in pedagogical theory.

\section{THEORETICAL ANALYSIS OF BASIC CONCEPTS}

Research of problems of development of education sphere in Ukraine is closely linked to the training of professionals capable of expert activity in this field. Such professionals should receive management and ecology training, be able to evaluate the content of education, the quality of educational services, carry out an expertise of the educational environment and provide advice to education managers and employees of all levels and types of educational institutions.

An important value for our research is the study of such concepts as «expertise», «expert», «consulting», «monitoring», «diagnostics», «audit», «inspection», «control», which will be a background for substantiating your own definitions of «expert activity» and «expert in the field of education».

Thus, the variability of interpretations of the concept of «expertise» indicates a different understanding of the authors of its types, functions and place. Considering a wide range of concepts, it should be noted that expertise is defined as: experts' consideration of a specific issue for conclusion (by definition of S. Ozhegov); consideration, study of a particular case, some issue with a view to draw the correct conclusion, give a correct assessment of the relevant phenomenon or research, expert's examination of any issues requiring special knowledge (by definition given in the Great Interpretive Dictionary of Modern Ukrainian Language, edited by V. Busel, 2005, p. 341); research by a specialist on issues that require special knowledge in the field of science, technology, art, etc. (by definition of the Great Encyclopaedic Dictionary, edited by A. Prokhorov) (Theoretical analysis of humanitarian expertise [URL resource]). According to I. Chechel (2012), the expertise is a reflection of practice, reconstruction of what has happened, identification of the most significant; it is considered as a kind of analysis of a separate study, which aims to relate perceptions of the object being expertised, as a result of the identified expert activity characteristics of the object.

We can summarize that expertise in scientific works is defined as a way of analyzing cause and effect relationships not only in relation to what has already happened, but also what is expected, should, or can happen.

S. Bratchenko (2006) views expertise as a study of reality, which allows one to see and understand what cannot be measured or calculated, because there are 
no formalized criteria and characteristics, approved normative acts, algorithms, etc. Expertise as a whole can be defined as a study of a question that has no evident answer but takes into account the opinion of specialists on a specific question.

The aim of the expertise in education can be conformity assessment concepts specific educational institutions of learning environment, and compliance with author's educational programs to the basic requirement - to create the conditions for manifestation of creative potential of students, and thus for the development of their physical, cognitive and personal abilities in the process of their socialization (Koval, \& Makarchuk, 2010, p. 26).

The expertise must be conducted in accordance with certain criteria. For example, toevaluatetheeffectiveness of educational programs shouldbe used socialand pedagogical indicators; qualification indicators (educational diplomas, certificates, etc.); educational standards (domestic, foreign); inclusion of other institutions of the region (educational, cultural, health) in the implementation of this program (Laktionova, 2008). Any expertise related to education in Ukraine is governed by the Law on Scientific and ScientificTechnical Expertise and certain other legal acts.

In recent decades, scientific expertise in the field of education has spread in Western countries, taking the form of "pedagogical audit», "psychological and pedagogical expertise», "comprehensive humanitarian expertise», etc.

Let us describe in more detail the humanitarian expertise. This concept started to be used in psychology in the late 80's. XX century. in connection with the participation of a group of psychologists (T. Dridze, J. Zhukov, A. Nazaretian, I. Syrotkina, A. Kharash) in the expertise of social project. A. Kharash formulated the concept of «humanitarian expertise» as a generalized assessment of «the effects that can or may have on a person (for the population of a region, one or another social group) or an event that has occurred in the past (distant or recent), is taking place in the present time or potentially possible in the near future» (Theoretical analysis of humanitarian expertise [URL resource]).

Humanitarian expertise (as defined by V. Kizima (2012) is an initial, permanent and independent institution of society, capable of adequately assessing not only the existing needs of society at all major levels of its activity, but also those that are maturing, which draws on an analysis of the current state of public consciousness and the objective dominants of the integral experiences of citizens.

O. Koval and I. Makarchuk (2010) formulate a thorough definition: humanitarian expertise is a kind of expertise that proceeds from the priority of social and human needs and values in the course of evaluating complex projects and making important management decisions. In general, the humanitarian expertise is focused on identifying the possibilities and ways of harmonizing innovative processes with all manifestations of social and natural life, facilitating the deployment and positive self-realization of the creative potential of society and each person while harmonizing with the natural conditions of their activity (p. 25).

The subjects of humanitarian expertise are legislative acts or projects, regulations of local self-government, national, regional and local action plans, scientific and technical programs and social risks related to their implementation, as well 
as state concepts and innovative projects in all spheres of activity (Mkrtichyan, 2005). S. Bratchenko (2006) defines the subjects of humanitarian expertise as those who study (pupils, students), teachers, educational process, lifestyle of the institution, environment and surroundings (p. 26).

The subject of humanitarian expertise is the risks; character and scale of social consequences of managerial decisions, as well as recommendations for enhancing positive social consequences and preventing, mitigating or overcoming negative ones (Kasyanova, 2014).

In general, the humanitarian expertise, as a systematic, complex interdisciplinary expert activity, provides an important function of controlling and organizing the educational environment.

The expertise in education is one of those branches of scientific and practical activity that is actively developing in the Western countries, which has already developed an extensive hierarchical system of «expert support of projects» (Leontev, \& Ivanchenko, 2008), in particular in the field of education. In fact, none of the educational innovation omits peer reviews on various stages of implementation and realization. Professional environments quickly emerged - expert societies, with expert training centres, discussing urgent and scientific problems of expertise in many periodicals.

The expertise of education is a mediated (through expert) cognitive process. This activity is directed to a specific object through the object of knowledge, which is intended to highlight in the object those properties and states that make up the purpose of this activity. The subject matter of education expertise is defined as the range of issues to be resolved in its implementation. Expertise - a relatively new technology in education, which scientists have proposed to minimize the differences between the project and the result of its implementation (Ivanchenko, \& Leonteva, 2006).

It should be emphasized that an expert (from lat. expertus - experienced) is defined as a competent person who is invited to resolve outstanding issues; highly skilled, specialist in a specific field of activity, who solves the problem, using his own experience and knowledge. Any person who has the necessary knowledge to prepare an opinion on the issues under study may act as an expert. The expert is personally responsible for the provided conclusions (Kasyanova, 2011). The expert performs the following functions (Kasyanova, 2014, p. 24): diagnostic, evaluation, prognostic, protective.

O. Bodnar (2008, p. 5), in his dissertation research, defines the concept of «educational experts», defining them as specialists in the field of education, with relevant professional competencies, analytical abilities and practical experience, sufficient for expert evaluation of pedagogical objects, phenomena and processes and forming expert conclusions to make management decisions.

In our opinion, expert activity requires not only highly qualified specialist but also appropriate training. Experts need to be trained for professional communication, it is important to technologize the procedures for conducting expert assessments in order to protect expert opinions from bias, political involvement, prejudice. 
According to scientists, expert training should be carried out based on basic training programs, namely (Ivanchenko, \& Leonteva, 2006): in-depth programs for training and advanced training of experts; educational programs for individuals involved in the decision to conduct and assign expertise.

To sum up, there is ambiguity in the definition of expertise in the scientific space, as well as the substitution of this concept by similar ones, such as monitoring, diagnostics, inspection, evaluation, audit, control, consulting, etc. The definitions of these concepts are set out in Table 1.

Table 1. Basic concepts

\begin{tabular}{|c|c|c|}
\hline Concept & Definition & Author \\
\hline Audit & $\begin{array}{l}\text { Form of examination, process of researching the activity } \\
\text { of an educational institution. }\end{array}$ & O. Kasyanova \\
\hline $\begin{array}{l}\text { Diagnosis } \\
\text { of quality } \\
\text { of pedagogical } \\
\text { activity }\end{array}$ & $\begin{array}{l}\text { The process of identifying and describing the current state } \\
\text { of pedagogical activity and its causes, objective tendencies } \\
\text { and predicting the quality of pedagogical activity - } \\
\text { the degree of compliance of its conditions, process } \\
\text { and result with certain criteria. }\end{array}$ & $\begin{array}{l}\text { O. Bondarchuk, } \\
\text { Gh. Yelnikova }\end{array}$ \\
\hline Inspection & $\begin{array}{l}\text { Evaluation of education workers, educational institutions } \\
\text { in terms of external sample based on generally accepted } \\
\text { norms. }\end{array}$ & O. Kasyanova \\
\hline Counselling & $\begin{array}{l}\text { Social and economic phenomenon that aims to solve } \\
\text { various tasks and provide intellectual support in various } \\
\text { spheres of society. }\end{array}$ & I. Bratyshhenko \\
\hline Control & $\begin{array}{l}\text { System of checks of compliance of the object's state } \\
\text { and its performance with the requirements, which } \\
\text { are reflected in the relevant directives and normative } \\
\text { documents; one of the operational management functions. }\end{array}$ & O. Zaychenko \\
\hline $\begin{array}{l}\text { Monitoring } \\
\text { in education }\end{array}$ & $\begin{array}{l}\text { A special system for collecting, processing, storage } \\
\text { and dissemination of information about the state } \\
\text { of education, forecasting based on objective data } \\
\text { and the dynamics of the main trends of development } \\
\text { and development of scientifically grounded } \\
\text { recommendations for management decisions on improving } \\
\text { the efficiency of the educational sector. }\end{array}$ & T. Lukina \\
\hline Evaluation & $\begin{array}{l}\text { Objective expertise with certification, inspection } \\
\text { and control in space science related to the control } \\
\text { of employees and the quality of education students } \\
\text { mastering specific knowledge. }\end{array}$ & O. Kasyanova \\
\hline
\end{tabular}

It should be emphasized that the concepts discussed above differ by their nature, purpose, objectives, functions, purpose, targets, content, participants, application, technology, methods, tools and results. However, scientists often substitute the concept of «expertise» for consultative activities. We believe that counselling is a tool in the implementation of expertise. When interpreted the results of the expertise, which needs further discussion and development of specific recommendations to address identified gaps or development plan of the institution, educational programs, etc., it becomes necessary consulting activity. We view expertise as an integrated activity that combines educational audit and educational consulting (Figure 1). 


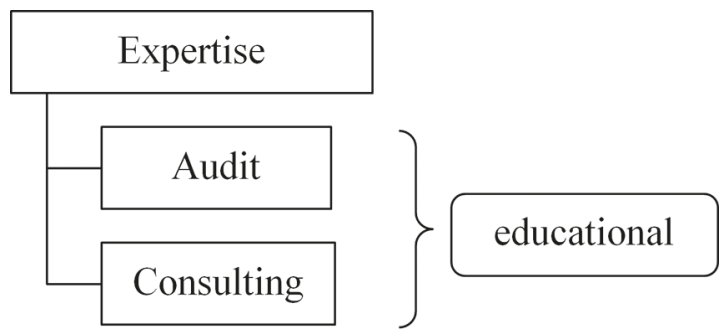

Figure 1. The complex concept of «expertise»

Analysis of the content of the concepts of the study allows us to study the key concept of our study - «expertise». Expertise is an integral part of the professional work of education experts who need to address educational challenges and situations. Without expert review of baseline data, terms, conditions, and other specific characteristics of the issue being investigated, education experts will not be able to objectively address them and provide guidance on how to resolve or improve the situation.

Therefore, the problem of examination as an integral part of professional activity in the field of education is important for training managers. According to Ukrainian researchers (Ognevyuk, \& Sysoieva, 2012), the first task of providing scientific support for the development of education should be to create and introduce in the higher education system new specialization in the training of experts in the field of education.

\section{CONCLUSIONS}

In the scientific space, the expertise is often identified with audit, diagnosis, inspection, consulting, control, monitoring, evaluation, etc. In the study, we proceed from the definition of expertise as a comprehensive scientific-cognitive or qualification procedure, which involves a comprehensive ascertaining the phenomenon, process, conditions of existence or course of phenomena, selected by the subject of expertise (by I. Manokha). Expert activities in education is considered by us to be a comprehensive analysis of the object under study in the sphere of education, which is carried out with the purpose of predicting its further development or correction and combines educational audit and educational consulting (Tryhub, 2017 , p. 55). An expert in the field of education is defined as an independent, highly qualified specialist who has a broad system of knowledge in the field of education and practical experience in providing competent assessment of the status of the object under study, forecasting its prospects and supporting development (Tryhub, 2017, p. 55).

Future scientific research will be devoted to the exploring and analysing the peculiarities of training experts in the field of education in Eastern Europe and to study the experience of work of the agencies for higher education quality assurance in the countries of Eastern Europe. 


\section{REFERENCES}

Bodnar, O. S. (2008). Organizational and pedagogical principles of expert evaluation ofeducational activities of secondary schools: Extended abstract of the dissertation : 13.00.06 (in Ukrainian). Kyiv, Ukraine, 20.

Bratchenko, S. L. (2006). The world of expertise - an attempt to determine the coordinates / In G. Ivanchenko, D. Leonteva (Eds.), Expertise in the modern world: from knowledge to activity (in Russian). M. : Smysl. - p. 63-76.

Busel, V. (2005). Great explanatory dictionary of modern Ukrainian Language (in Ukrainian). Kyiv. Ukraine, 1728.

Chechel, I. D. (2012). Expert-consultant on education: features of preparation and activities, 3 (82-85). http://iuorao.ru/20120930/222 $2012 \neg 10 \neg 02 \neg 08 \neg 55 \neg$ 39 (in Russian).

Ivanchenko, G. V., \& Leonteva D. A. (Eds.) (2006). Expertise in the modern world: from knowledge to activity (in Russian). M. : Smysl. - 452.

Kasyanova, O. M. (2011). Expert in education: basic characteristics, methods of selection and assessment, 21 (74), 78-86 (in Ukrainian).

Kasyanova, O. M. (2014). Control and analytical activity of the head of the educational institution. Kharkiv, Ukraine, 192 (in Ukrainian).

Kizima, V. V. (2012). Being is like a totality. Modern philosophical picture of the world and its applications, 27 (71-189). (in Russian).

Koval, O. A., \& Makarchuk, I. O. (2010). Humanitarian expertise in the information society education space, 2 (24-28). (in Ukrainian).

Laktionova, E. B. (2008). An analytical review of the main approaches to the psychological expertise of the educational environment, 11(68), 18-32 (in Russian).

Leontev, D. A., \& Ivanchenko G. V. (2008). Integrated human expertise: methodology and meaning (in Russian). Moscow, 135.

Mkrtichyan, R. A. (2005). Psychological and pedagogical expertise of innovations in education, 1(6), 152-155 (in Russian).

Ognevyuk, V., \& Sysoieva, S. (2012). Educology - is a scientific area of integrated study of education, (4/5), 44-51 (in Ukrainian).

Ognevyuk, V., \& Sysoieva, S. (2015). Training of educational experts in Ukraine: experimental interdisciplinary program. The advanced science journal, (6), 98103, https://doi.org/10.15550/ASJ.2015.06.098

http://www.enqa.eu/http://bo0k.net/index.php?p=achapter\&bid=16734\&chapter $=1$ (in Ukrainian).

Tryhub, I. I. (2017). Professional training of experts in the field of education in countries of Eastern Europe. Dissertation: 13.00.04 (in Ukrainian). Kyiv, Ukraine, 341. 


\section{ЕКСПЕРТИЗА У ГАЛУЗІ ОСВІТИ: ТЕОРЕТИЧНИЙ АНАЛІЗ БАЗОВИХ ПОНЯТЬ}

Тригуб Ілона, кандидат педагогічних наук, науковий співробітник, науково-дослідна лабораторія освітології, Київський університет імені Бориса Грінченка, вул. Тимошенко, 13-б, 04212 Київ, Україна, i.tryhub@kubg.edu.ua

Стаття присвячена теоретичному аналізу базових понять проблеми експертизи у галузі освіти. У науковому просторі поняття «експертиза» трактується по різному, зокрема, як цілісна науково-пізнавальна чи квалібікаційна процедура, яка передбачає комплексне констатуюче вивчення явища, процесу, умов існування чи перебігу явищ, що обираються предметом експертизи (I. П. Маноха).

Визначено, що у науковій літературі прослідковується неоднозначність у визначенні експертизи, а також підміна цьвого поняття подібними, такими як моніторинг, діагностика, інспектування, оцінка, аудит, контроль, консультування, тощо (визначення перелічених понять подано у тексті статті). Зазначено, що наведені поняття різняться між собою за своєю сутністю, метою, завданнями, функціями, призначенням, об'єктами, змістом, учасниками, застосуванням, технологіями, методами, інструментарієм та результатом діяльності. Автор розглядаємо експертизу як комплексний вид діяльності, що має поєднувати освітній аудит та освітній консалтинг. Зокрема, аудит є формою експертування, процесом дослідження діяльності навчального закладу (О. М. Касьянова), а консультування - соціальним та економічним явищем, що ставить за мету вирішення різноманітних завдань і надання інтелектуальної допомоги в найрізноманітніших сферах життєдіяльності суспільства (I. В. Братищенко).

У статті уточнено теоретичну сутність понять: «експертна діяльність в освіті» та «експерт у галузі освіти». Відтак, експертна діяльність в освіті визначається як комплексний аналіз досліджуваного об'єкту у сфері освіти, що здійснюється з метою прогнозування його подальшого розвитку чи корекції та поєднує в собі освітній аудит та освітній консалтинг. Експерт у галузі освіти визначається ж як незалежний висококваліфікований фахівець, який володіє широкою системою знань у сфері освіти та практичним досвідом з надання компетентної оцінки стану досліджуваного об'єкту, прогнозування його перспектив та підтримки розвитку.

Ключові слова: аудит; діагностика; експерт у галузі освіти; експертиза; експертна діяльність в освіті; інспектування; консультування; контроль; моніторинг; оцінка.

Received: 03.12.2019

Accepted: 26.12.2019 